\title{
GEOGRAPHIC INFORMATION SYSTEM AND ANALYTICAL HIERARCHY PROCESS FOR LAND USE PLANNING OF BEEKEEPING IN FOREST MARGIN OF BOGOR REGENCY, INDONESIA
}

\author{
Widiatmaka $^{1 *}$, Wiwin Ambarwulan ${ }^{2}$, Chandrasa E. Sjamsudin ${ }^{3}$ and Lailan Syaufina ${ }^{4}$ \\ ${ }^{1}$ Department of Soil Science and Land Resources, Bogor Agric. Univ., Bogor, 16680, Indonesia \\ ${ }^{2}$ Geospatial Information Agency, Cibinong, 16911, Indonesia \\ ${ }^{3}$ Study Program of Environmental Management, Bogor Agric. Univ., Bogor, 16680, Indonesia \\ ${ }^{4}$ Department of Silviculture, Bogor Agric. Univ., Bogor, 16680, Indonesia \\ *Corresponding author: widiatmaka@ipb.ac.id; widi.widiatmaka@yahoo.com
}

\begin{abstract}
One way to establish forest conservation is by improving the welfare of the community residing at the forests' borders. Beekeeping has the potential to increase the income of the people around the forest. This study aims to delineate beekeeping zones bordering the forest regions. Multi-criteria analysis based geographic information system was used to delineate the ecologically suitable areas for honey bees. The parameters used included physical parameters (temperature, rainfall, distance from water source and altitude), economic parameters (distance from the roads and distance from the market) and social parameters (land use and distance from settlements). The parameters were weighed by applying analytical hierarchy process. The result was then inputted into a spatial model designed to determine the ecological suitability for honeybees. The suitable land for bees' forages was delineated using land suitability analysis with maximum limitation method. The results of both analyses were then overlaid to delineate suitable areas for beekeeping. The analysis resulted in locating recommended areas for the cultivation of honey bees and forages around the forest periphery, by taken into account official spatial land use planning.
\end{abstract}

Key words: Habitat suitability, land suitability, bee forage, land use planning

\section{INTRODUCTION}

The extent of Indonesian deforestation is quite extensive (Menhut RI 2016). There are many factors that cause such deforestation, among others the extraction of timber and forestry by wood industries which led to large-scale forest exploitation, but also due to exploitation by communities around the forest (Widiarti and Kuntadi 2012). Facing such a situation, in recent years Indonesia carried out a paradigm shift regarding forestry development policies. There was a gradual shift from the original forestry policy that focused only on the management of timber forest products to one that also approaches it through natural resource management (Rachmawati et al. 2014; Kusmana C. 2011. Beekeeping is among one of the income-generating activities that can be developed in the forest fringes. This cultivation may encourage people to participate in forest preservation (Park and Yeo-Chang 2012). Honeybees are also very valuable biological resource because of their role in the pollination of various crops (Hannon and Sisk 2009; Van Engelsdorp and Meixner 2009).

The demand for honey production in Indonesia has increased in recent years due to the population growth in addition to the buildup of growing awareness of healthy living. Indonesia also has potential advantage on biological resources, supported by the presence of various types of Indonesian native bees, diverse types of food plants for bees forage and agro-climatic conditions that are conducive to the cultivation of bees (Widiarti and Kuntadi 2012). With the current consumption of honey at 15 g.person-1.year-1 (Menhut RI 2016) and with a total population estimated at 250 million in 2014 , the need of honey bee is expected to be at least at 3,750 tons.year-1. This requirement is actually difficult to be met because the current supply is at the range of 1500 2000 tonnes.year-1 (Roman 2006).

To be successful in beekeeping, one of the prerequisites is to ensure the availability of feed as bee forage. Usually, bee's forage is abundantly available in the forest. However, a continuous supply of bee forage plants must always be available when bees are to be cultivated as a commodity in agribusiness. Bee forage plants are vegetation inherently grown and cultivated, which produce nectar and/or pollen that can be taken by honeybees as their feed (Adeva 2012).

Beekeeping need to consider the habitat's suitability, based on its ecological environment as well as land suitability for the feed source. Geographic information systems (GIS) have the ability to develop a model in the framework of land suitability evaluation (Elsheikh et al. 2013). The habitat suitability models can be built through a multi-criteria evaluation approach, which integrates expert's knowledge (Store and Jokimaki 2003; Akınc1 et al. 2013). This method has been conducted among others to evaluate the suitability of habitat for bees (Estoque and Murayama 2010), in 
addition to other uses (Hossain and Das 2010). Multicriteria evaluation techniques use a combination of GIS (Malczewski 2006) and Analytical Hierarchy Process (AHP) (Saaty 1988) to determine the suitability of the ecological habitat of a species. Such process integrates spatial analysis which allows data from various sources to be processed together in an integrated manner by giving the attributes of its geographical position as a key connecting factor.

The objective of this study was to analyze the suitability of honeybees' habitat and to analyze the land suitability of several plant sources for bee forage. The results of the two analysis were then used to analyze the land suitability for beekeeping. This analysis is expected to provide direction for the development of beekeeping at the forest fringe of Bogor Regency.

\section{METHODOLOGY}

\section{Study Area}

The study was conducted in Bogor Regency, West Java Province, Indonesia. The area of the region is 2 $301.95 \mathrm{~km}^{2}$, which encompasses $5.19 \%$ of West Java Province (Bogor Regency Statistics 2013). The region is geographically located at $6.19^{\circ} \mathrm{N}-6.47^{\circ} \mathrm{S}$ and $106^{\circ} 1^{\prime}$ $107^{\circ} 103^{\prime} \mathrm{E}$. The study area has a wet tropical climate with an annual rainfall average of $3992.7 \mathrm{~mm}$. The average air temperature in 2013 ranged from $25.1^{\circ} \mathrm{C}$ to $26.4^{\circ} \mathrm{C}$. The landform varies, from low-altitude flat area in the northern part to high-altitude mountainous area in the southern part.

\section{Procedure and Data}

This study is focused on the analysis of bee farming cultivated outside of the forest area status, but still within the forest edge. As a first step, delineation was done to separate the forest zone with the cultivation areas. In such cultivation area, the multi-criteria analysis for bees' growth environment was done. Land suitability analysis was also performed to analyze the suitability of some bees forage crops. The results of the two analysis were then overlaid to obtain the suitable area for the cultivation of bees. The corresponding region was overlaid with the map of Official Spatial Land Use Planning (OSLUP), to ensure that the region is officially allowed for cultivation.

Data on the forest area status was obtained from (Forest Planning Agency 2009), in the form of a Forest Areas Status (FAS) map with a scale of $1: 50$ 000. The forest areas were separated from the non-forest area, defined as "area for other utilization" (AOU). The analysis of land use planning for beekeeping is only carried out on AOU zones. Land use and land cover of the study area were analyzed using Ikonos imagery of 2012. Analyses were performed with image interpretation software, using the supervised classification. Field visits were conducted to check the results of the interpretation. Slope and elevation map was made using 1: 25000 topographic maps from Indonesian Geospatial Information Agency. Data of roads and rivers which will be used for buffering the distance from the road and river were also obtained from this map. Temperature and rainfall data were obtained in spatial form from the Meteorology and Geophysics Agency. Soil map for Bogor was compiled from various studies which later on was merged in this research to become Land Unit Map of Bogor Regency. The Official Spatial Land Use Plan (OSLUP) map of Bogor Regency was obtained from the Office of Regional Planning of Bogor Regency.

\section{Multi-criteria Analysis for Ecological Habitat Suitability}

The analysis of ecological habitat suitability for honey bee is done by multi-criteria analysis, an analysis using the principle of the weighted linear combination (WLC). The structures of the AHP used in this research consist of: parameter, criteria and sub-criteria. The parameters are made up of ecological-, social- and economic parameter. The criteria for the ecological parameter include height above sea level, slope, temperature, rainfall and distance from the river. The economic parameter covers the distance from the road and the market. The social parameter takes into account the distance from settlements and existing land utilization. In each criteria, there are sub-criteria which define the suitability, these were established by interviews with the stakeholders consisting of experts and farmers bees. Suitability was classified into three levels: 3 (highly suitable), 2 (suitable), 1 (marginally suitable) and 0 (not suitable) (Table 1).

The weight of each parameter and criteria were obtained through an AHP approach. In AHP, parameter, criteria and sub-criteria that affect the classification of the location of the habitat is weighed through interviews with stakeholders and experts, in this study five experts were involved. Weighed values obtained from AHP analysis is used to determine the equation of WLC. WLC incorporates a number of factors and weighing in a summation equation to generate a suitability map that is expressed in a mathematical equation (Banai 1993).

In the AHP method, the criteria were measured up in pairs to compare the level of importance. The level of importance is scaled from 1 (not important) to 9 (very important). The results of pair-wise comparison in this study are presented in Table 2 and Table 3. Consistency ratio obtained was amounted to 0.001 , indicates that the process done is valid, far below the validity threshold of CR $<0.1$ (Saaty 1988).

Results of such process are subsequently used as a weighing factor in the spatial analysis. WLC equation is used to determine the habitat suitability map of honeybee through the process of field calculator on spatial data processing. In practical, the value used was the value of multiplication between the weights of parameters, criteria and the suitability scores of subcriteria. The interval value for the honey bee habitat suitability is then determined with equal distance. 
Table 3. Matrix of pair-wise comparison to assess the relative importance of parameter for habitat beekeeping suitability

\begin{tabular}{|c|c|c|c|c|}
\hline & Biophysic & Social & Economy & Weight \\
\hline \multicolumn{5}{|c|}{$\begin{array}{l}\text { Criteria requirement in assessing the site's } \\
\text { suitability for beekeeping }\end{array}$} \\
\hline Ecology & 1 & 2 & 2 & 0.50 \\
\hline Social & $1 / 2$ & 1 & 1 & 0.25 \\
\hline Economy & $1 / 2$ & 1 & 1 & 0.25 \\
\hline
\end{tabular}

Max eigenvalue ( max $)=3$

$n=3$

Consistency index $(\mathrm{Ci})=(\gamma \max -n) /(n-1)=0.00$

Random index $(\mathrm{Ri})=0.58$

Consistency ratio $(\mathrm{Cr})=\mathrm{Ci} / \mathrm{Ri}=0.001$

\section{Land Evaluation for Bee Forage}

Five different types of bee forage as a priority in analyzing its suitability were chosen. Of the five species selected, partly are perennial plants (Randu, Rambutan, Rubber), some are annual crops (Cucumber, Corn, Pare). The choice of annual crops was done on purpose so that there are plants available that can be used before the perennial plants are harvested. The choice of plants to be analyzed is also based on the flowering period and pollen or nectar production period.

The land suitability analysis for such bee forage was performed to each land unit by using the maximum limitation method (FAO 1976), The land unit used is a land unit of soil map of Bogor Regency at scale of 1 : 50 000, which is compiled from the results of previous mapping (Atmosentono 1968; Pusat Penelitian Tanah 1981). Based on these maps, Bogor Regency consists of 41 land units. For each land unit, the results of laboratory analysis of soil samples were also taken from such secondary data. In this analysis, comparisons were carried out between the land characteristics and land requirement, which is reflected in the criteria used (Badan Penelitian dan Pengembangan Pertanian 2002).

\section{RESULT AND DISCUSSION}

\section{The Forest Area of Bogor Regency}

The total area, which includes the forest, is 75679 ha and represents $25.4 \%$ of the total area of Bogor Regency (Fig. 1). The remaining $74.6 \%$ of the region are zones outside the forest area. It should be noted that the area inside FAS does not actually usually have forest land cover. There are some actual land utilizations which are forbidden inside FAS, such as rice fields and settlements.

\section{Habitat Suitability for Beekeeping.}

According to the result of AHP, the ecological parameters appeared to have a higher influence than the social-and economic parameters in determining suitable habitats for the honey bees. For the ecological parameters, the temperature and rainfall criteria have a high weight in determining the habitat suitability for honey bees. Both of these criteria have the same weight. The next criteria is the height above sea level, followed by the criteria of the distance from the river. The temperature has a significant effect on the fertility of bee queen as well as the flying activity of bees to find feed. The main factors inhibiting the activity of honeybees in searching for food are low temperature and high rainfall (Markwell et al. 1993). The weather thus has a direct effect on the productivity of bee colonies (Abou-Shaara et al. 2013). Long periods of

Table 1. Parameter's suitability used for habitat ecological analysis of honey bee

\begin{tabular}{|c|c|c|c|c|}
\hline $\begin{array}{c}\text { Land } \\
\text { Characteristic }\end{array}$ & $\begin{array}{c}\text { S1 } \\
\text { (Highly Suitable) } \\
\text { (3) }\end{array}$ & $\begin{array}{c}\text { S2 } \\
\text { (Moderately } \\
\text { Suitable) } \\
(2)\end{array}$ & $\begin{array}{c}\text { S3 } \\
\text { (Marginally } \\
\text { Suitable) } \\
(1)\end{array}$ & $\begin{array}{c}\mathrm{N} \\
(\text { Not Suitable) } \\
(\mathbf{0})\end{array}$ \\
\hline $\begin{array}{l}\text { Temperature } \\
\left({ }^{\circ} \mathrm{C}\right)\end{array}$ & $24-27$ & $\begin{array}{l}20-24 \\
27-30\end{array}$ & $\begin{array}{l}15-20 \\
30-35\end{array}$ & $\begin{array}{l}<15 \\
>35\end{array}$ \\
\hline Rainfall (mm) & $2000-2500$ & $\begin{array}{c}2500-3000 \\
1500-2000\end{array}$ & $\begin{array}{l}3000-3500 \\
1200-1500\end{array}$ & $\begin{array}{l}>3500 \\
<1200\end{array}$ \\
\hline Height (m a.s.l.) & $250-500$ & $\begin{array}{c}150-250 \\
500-1000\end{array}$ & $\begin{aligned} 100 & -150 \\
1000 & -1500\end{aligned}$ & $\begin{array}{c}<100 \\
>1500\end{array}$ \\
\hline $\begin{array}{l}\text { Distance to } \\
\text { River (m) }\end{array}$ & $<500$ & $500-1000$ & $1000-2000$ & $>2000$ \\
\hline $\begin{array}{l}\text { Distance to } \\
\text { Settlement }(\mathrm{m})\end{array}$ & $1000-2000$ & $\begin{array}{c}500-1000 \\
2000-3000\end{array}$ & $\begin{aligned} 200 & -500 \\
3000 & -4000\end{aligned}$ & $\begin{array}{l}<200 \\
>4000\end{array}$ \\
\hline Landuse & $\begin{array}{l}\text { Moor/field, mixed } \\
\text { farming, grass, } \\
\text { barre land, shrub } \\
\text { forest, forest, shrub }\end{array}$ & 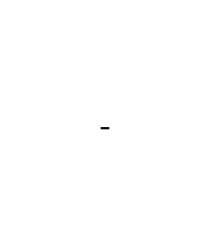 & $\begin{array}{l}\text { plantation, } \\
\text { rocky land }\end{array}$ & $\begin{array}{c}\text { Built land, swamp, village, } \\
\text { settlement, Emplacement, mining, } \\
\text { golf course, industry, livestock, } \\
\text { irrigated paddy field, non-irrigated } \\
\text { paddy field freshwater pool, lake, } \\
\text { river }\end{array}$ \\
\hline $\begin{array}{l}\text { Distance to } \\
\text { Market }\end{array}$ & $0-2000$ & $\begin{array}{c}2000-4 \\
000\end{array}$ & $>4000$ & \\
\hline $\begin{array}{l}\text { Distance to } \\
\text { Main Road }\end{array}$ & $0-500$ & $500-1000$ & $>1000$ & \\
\hline
\end{tabular}


rain and cold weather have an adverse effect on the productivity of honey bees because bees remain in the hive (Van Engelsdorp and Meixner 2009). Given that Bogor Regency is a region with high rainfall, it is predicted that many areas are not ecologically suitable for the cultivation of bees. Altitude has a close relation to the temperature. In accordance with Braak's formula (Rachmawati et al. 2014), with each $100 \mathrm{~m}$ increment above sea level, the temperature will drop by $0.5^{\circ} \mathrm{C}$. In Bogor Regency where hilly and undulating landforms are dominant, altitude factors are predicted to affect greatly the suitability of various living beings.

Table 2. Matrix of pair-wise comparison to assess the relative importance of habitat criteria for beekeeping suitability Temperature Rainfall Height Distance to River Weight

\begin{tabular}{lccccc} 
& Temperature & Rainfall & Height & $\begin{array}{c}\text { Distance to } \\
\text { River }\end{array}$ & Weight \\
\hline Ecology & 1 & 1 & 2 & 3 & 0.351 \\
Temperature & 1 & 1 & 2 & 3 & 0.351 \\
Rainfall & $1 / 2$ & $1 / 2$ & 1 & 2 & 0.189 \\
Height & $1 / 3$ & $1 / 3$ & $1 / 2$ & 1 & 0.109 \\
Distance to River & & & & \\
Consistency ratio $(C r) 0.004511344$ & & & & \\
\hline
\end{tabular}

\begin{tabular}{lccc}
\hline & Distance to Settlement & Land Use & Weight \\
\hline Social & 1 & $1 / 2$ & 0.333 \\
$\begin{array}{l}\text { Distance to Settlement } \\
\text { Land Use }\end{array}$ & 2 & 1 & 0.667 \\
Consistency ratio $(\mathrm{Cr})=0$ & & & \\
\hline \multicolumn{2}{l}{ Distance to Market } & Distance to Main Road & Weight \\
\hline Economy & 1 & $1 / 2$ & 0.333 \\
$\begin{array}{l}\text { Distance to Market } \\
\text { Distance to Main Road }\end{array}$ & 1 & 0.667 \\
Consistency ratio $(\mathrm{Cr})=0$ & 2 & & \\
\hline
\end{tabular}

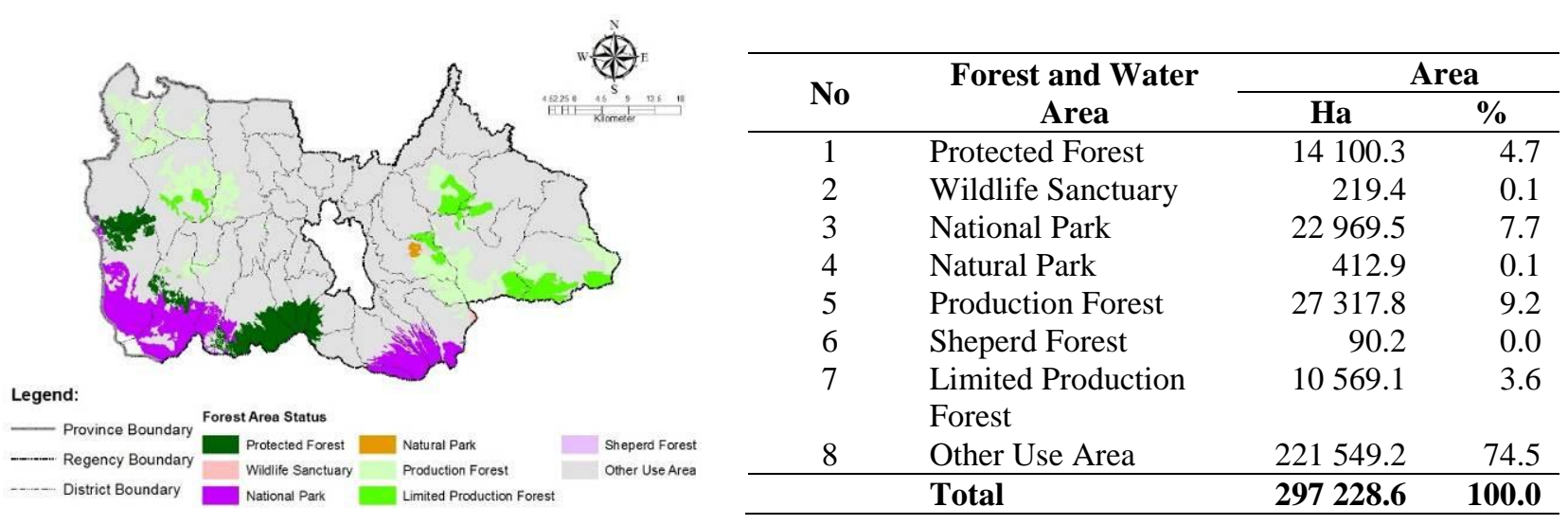

Figure 1. Forest status area of Bogor Regency according to Map of Forest Status Area

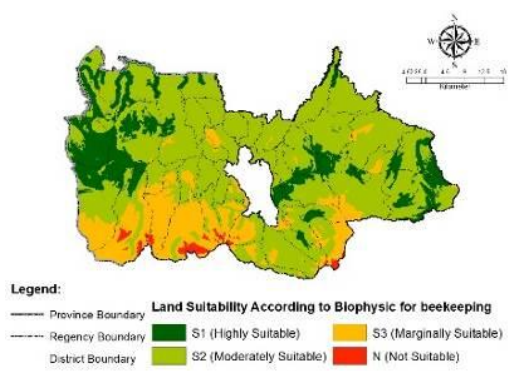

(a)

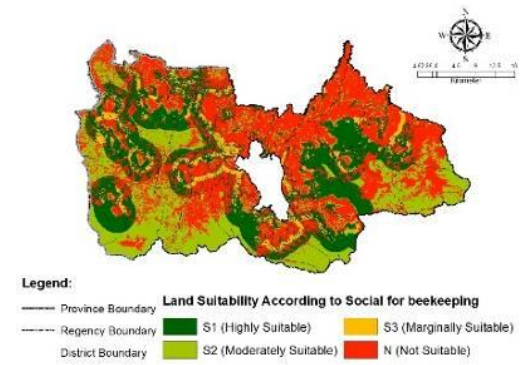

(b)

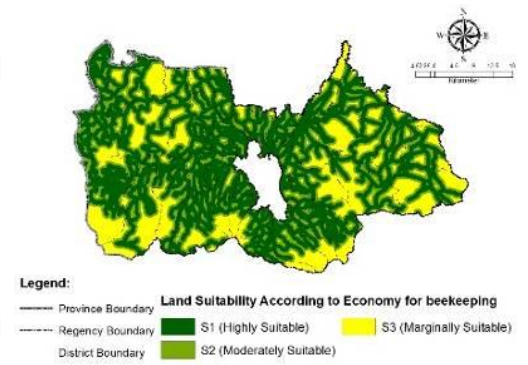

(c) 


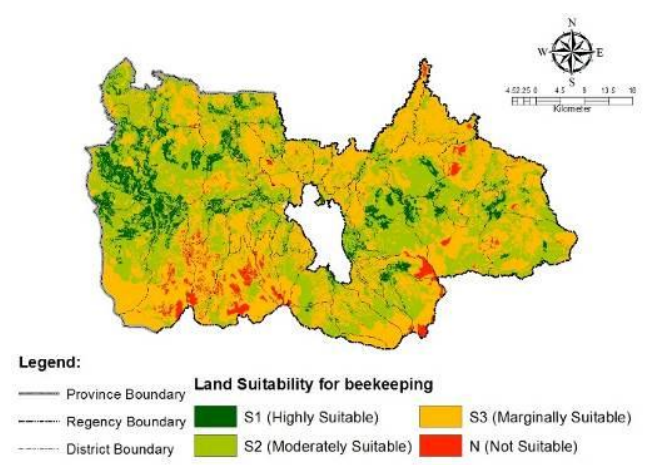

(d)

Figure 2. Habitat suitability for bee according to: (a) biophysical suitability, (b) social suitability, and (c) economical suitability, (d) overall habitat suitability for honey bee

The flight activity of several bee species is related to moderate temperatures, high relative humidity and daily foraging cycle in particular during the early morning flight activity (Giannini et al. 2012). Precipitation can forecast the abundance of honey bee; more colonies and swarm removals would occur after following wet seasons, while fewer would do so following dry seasons (Baum et al. 2008).

The distance from the river affects the habitat suitability of bees related to water resources availability. Water is needed by bees to meet their needs and to wet the pollen so it will be easily eaten. However, if the distance is too close to the river, the honey will absorb moisture from the river and will have a too high water content. Good location for the maintenance of honey bee is one that has good drainage, safe from flooding and is near water sources (Baum et al. 2008).

On social factors, land use and agricultural landscape has a higher weight than the distance to the settlement (Hannon and Sisk 2009). Land use may support the availability of food resources for bees. The effect of the distance to the settlement was associated with two (2) different major consequences. Beekeeping should be done near home growers to ease the management of the activity, however, it also should not be conducted too close to avoid any disturbances for both the human and the bees. Actual land utilization also has ecological aspects, although it is included in the social aspect because of the limited land availability in Java Island.

On the economic factor, the distance to the roads has a higher weight than the distance to the market. Both of these factors refer to the ease of marketing. However, when we assess the economic aspect, the comfort of the bees should also be taken into consideration. Vehicles travelling on highways usually contain heavy metals. This would give a bad effect on the bees. The location of apiculture should be safe from toxins and chemicals (FAO 1990). Since honey is a hygroscopic substance, it will absorb the pollutants. The noise emitted by vehicles on the road will disturb the bees.

The weights obtained from AHP analysis were then used to generate the ecological suitability map (Fig. 2a), social suitability (Fig. 2b), and economical suitability (Fig. 2c). The overall habitat suitability for honey bees was given in Fig. 2d.

In determining the map of habitat suitability for honeybees, a number of constraints have to be taken into consideration. Constraint was standardized using Boolean scale of 0 or 1 . Constrained used in this analysis consist of the land characteristics mentioned as sub-criteria $\mathrm{N}$ (not suitable) in Table 1 . Honey bee habitat suitability maps were reclassified based on deployment habitat suitability value of bees and honey bee productivity in Bogor. Suitability classes are divided into 4 classes with equal intervals (Fig. 2d).

\section{Land Suitability for Bee Forage}

\section{Land suitability for annual crops (Kapok Randu, Rubber and Rambutan).}

Kapok plant is one of the important plant sources for bee feed as the flowers produce nectar and pollen. The honey bee harvest season in several regions coincided generally with the period of Kapok flowering (Menhut RI 2016). The majority area around Bogor Regency is not suitable (N) for Kapok (Fig. 3a). The main limiting factor is water availability, in this case the rainfall and rooting media. Most of the district of Bogor has a rainfall ranging from 2000 to $4500 \mathrm{~mm}$.year-1, while Kapok thrives during long dry seasons, but not too dry. West Java Province is an area that is too wet to cultivate Kapok (Menhut RI 2016). The rainfall in dry periods will determine the flowering time and fruit formation.

Rubber (Hevea braziliensis) is an annual plant that can grow well in Bogor. Land suitability analysis results (Fig. 3b) shows that many parts of Bogor Regency was suitable for rubber. Although the quality pollen for bee feed is not as good as kapok, but this plant can also be an important source of bee forage.

Rambutan plants grow well also in Bogor Regency. Many parts of Bogor Regency was suitable for rambutan (Fig 3c). The limiting factor that often arises are water availability. One of the advantage of using this plants as bee forage are the resulting honey bees which has a distinctive rambutan aroma that is quite interesting.

\section{Land suitability for annual crops (Corn, Cucumber and Pare).}

Corn (Zea mays), Cucumber (Cucumis sativus) and Pare (Momordica charantia) are plants in which farmers are cultivated in Bogor Regency. These plants produce a lot of nectar and pollen that is highly favored by bees. Most of the land has a land suitability level of S3, and partially unsuitable. Pare plants appear to have a higher degree of suitability (Fig. 3d, 3e and 3f). 
Land Use Planning for Beekeeping Based on Bee Habitat Suitability and Suitability of Bee Forage

During the next step, a planning was done to select the area with a realistic bee forage combination. Fig. $4 \mathrm{a}$ presents a map of the area which is suitable for all 6 types of feed bees. This is the ideal region from a view point of the bee forage, in which 6 types of bee forage is suitable. This figures shows that very few areas are suitable to accommodate 6 types of feed bees. This is because there are very few regions which are suitable for kapok while concurrently being also suitable the 5 other bee forage. Due to the narrowness of such area, in Fig. $5 \mathrm{~b}$ presents the area suitable for 5 types of bee forage, while removing kapok.

Afterwards, analysis was done to combine areas that are suitable for bees' habitat and available in bee forage (Fig. 5). This is the results of overlay between habitat suitable areas for beekeeping and area where 6 types of bee forage are suitable (Fig. 5a) and area where five types of bee forage are suitable (Fig. 5b).
At the final step, we make the recommendations for the development of the honey bee area expansion (Fig. 6 ). The recommendations put forwards 3 (three) area resulting from overlay, according to their priority. The first priority is an area that is suitable for bee habitat while at the same time also be suitable for 6 types of feed forage. The second priority is an area that is suitable for bee habitat and suitable for 5 kind of forage without kapok. The third priority is an area which is suitable for bee habitat and suitable only for less than 5 kind of forage. All of the recommended areas are areas which allow bee cultivation according to OSLUP. Thus, there are 1130.7 ha (4.6\%) area of priority I, 15543.3 ha $(63.5 \%)$ area of priority II and 2270.1 ha $(9.3 \%)$ area of priority III to be recommended for beekeeping. There are 5542.2 ha $(22.6 \%)$ area resulting overlay which are not suitable because not suitable at least for habitat or for bee forage.

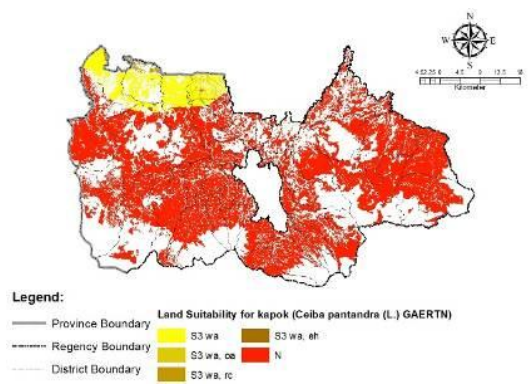

(a)

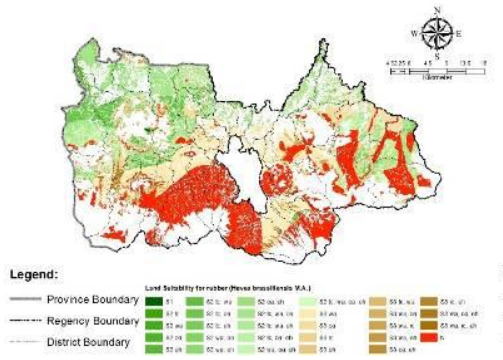

(b)

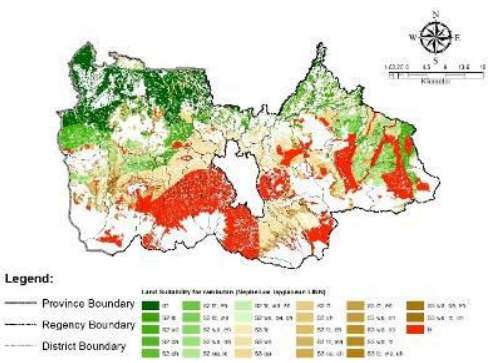

(c)

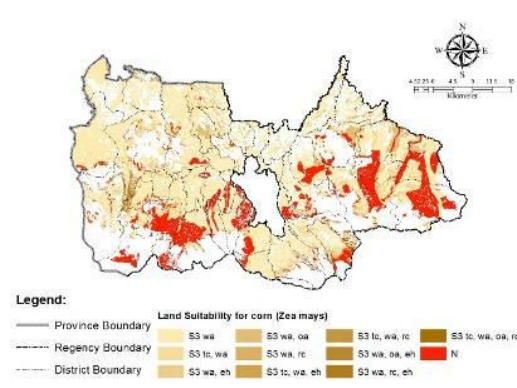

(d)

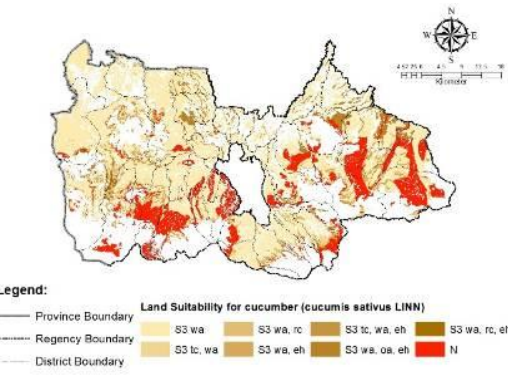

(e)

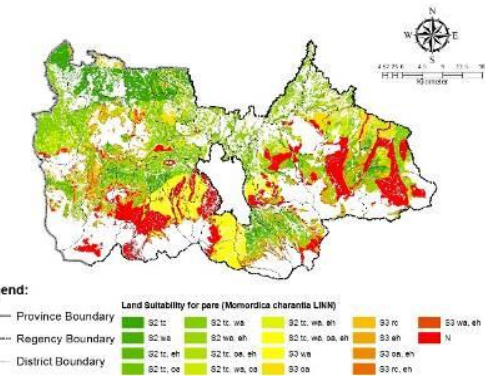

(f)

Figure 3. Land suitability for bee feed: (a) Kapuk Randu, (b) Rubber, (c) Rambutan, (d) Corn, (e) Cucumber, and (f) Pare

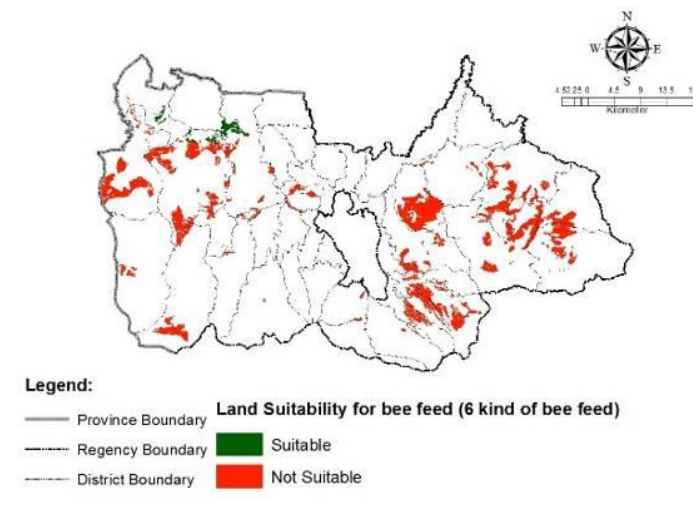

(a)

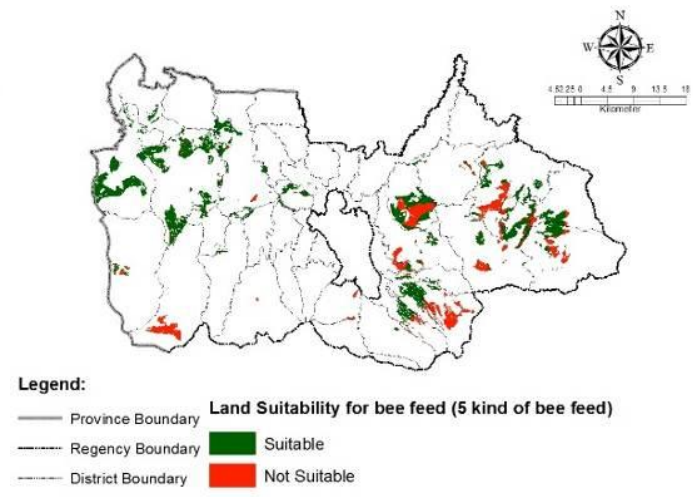

(b)

Figure 4. Land Suitability for bee forage: (a) 6 kind of bee forage, and (b) 5 kind of bee forage 


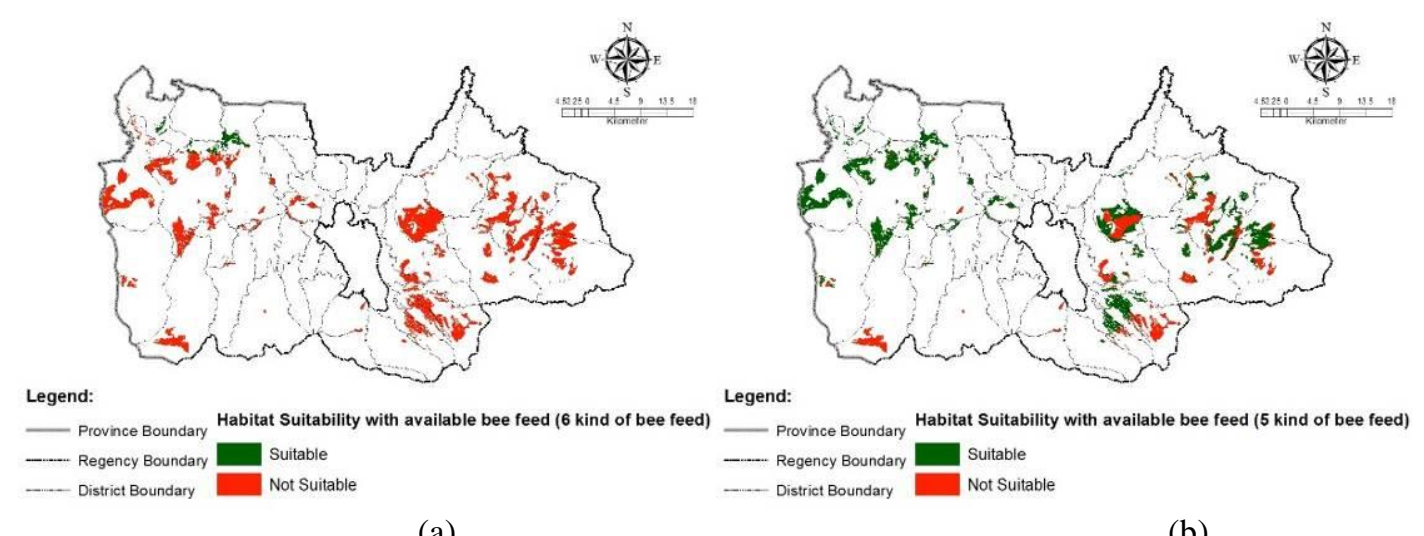

(a)

(b)

Figure 5. Suitability for beekeeping with available bee forage for: (a) 6 kind, and (b) 5 kind

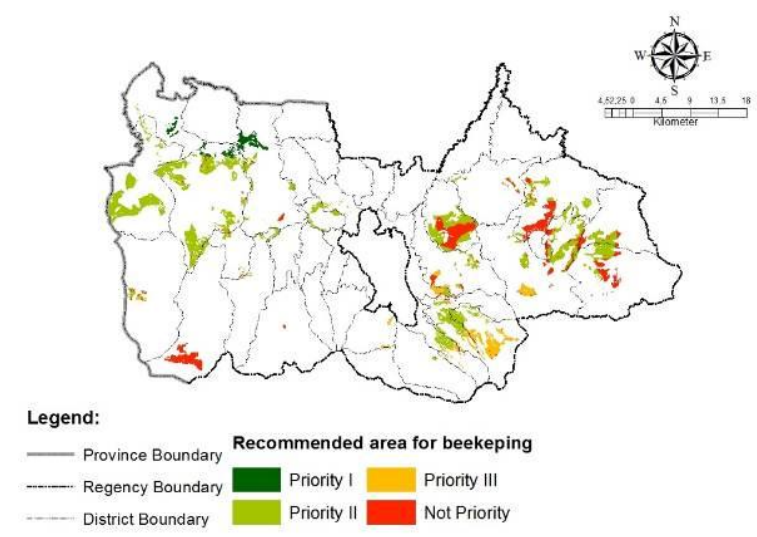

Figure 6. Recommended area for beekeeping in forest margin of Bogor Regency with 3 priority recommended areas

\section{CONCLUSION}

Steps of analysis have been conducted to delineate suitable areas for beekeeping on the forest fringe of Bogor Regency. The analysis was carried out within the framework of securing forest area. As the first step, an analysis is performed using a combination of GIS and AHP method to delineate suitable area for the bee's habitat. The result showed that biophysical parameters have the most influence. Land suitability analysis for bee forage was then done in the next step, using the method of maximum limitation. A combination between the two analyzes are successfully delineate the area that is suitable for bee habitat and suitable for bee forage. Furthermore, taking into account OSLUP, priority area on the forest fringe was recommended for the development of beekeeping. The area were recommended as the first priority (1 $130.7 \mathrm{ha})$, second priority (15 $543.3 \mathrm{ha}$ ), and third priority (2 $270.1 \mathrm{ha}$ ).

\section{REFERENCES}

Abou-Shaara HF, Al-Ghamdi AA, Mohamed AA. 2013. A suitability map for keeping honey bees under harsh environmental conditions using Geographical Information System. World Applied Sciences Journal 22(8): 1099-1105

Adeva JJG. 2012. Simulation modelling of nectar and pollen foraging by honeybees. Biosystems Engineering 112: 304-318.
Akıncı H., Ozalp AY and Turgut B. 2013. Agricultural land use suitability analysis using GIS and AHP technique. Computers and Electronics in Agriculture 97: 71-82.

Atmosentono H. 1968. Tanah-tanah di sekitar Bogor. Lembaga Penelitian Tanah. Bogor

Badan Penelitian dan Pengembangan Pertanian. 2002. Kriteria kesesuaian lahan. Departemen Pertanian

Banai R. 1993. Fuzziness in geographic information systems: Contributions from the analytic hierarchy process. International Journal of Geographical Information Systems 7(4): 315329.

Baum KA, Tchakerian MD, Thoenes SC, Coulson RN. 2008. Africanized honey bees in urban environments: A spatio-temporal analysis. Landscape and Urban Planning 85: 123-132.

Bogor Regency Statistics. 2013. Bogor Regency in figures. Indonesian Statistics

Elsheikh R, Rashid A, Shariff M, Amiri F, Ahmad NB, Balasundram S, Soom MAM. 2013. Agriculture Land Suitability Evaluator (ALSE): A decision and planning support tool for tropical and subtropical crops. Computers and Electronics in Agriculture. 93: 98-110.

Estoque RC, Murayama Y. 2010. Suitability analysis for beekeeping sites in La Union, Phillipines usig GIS and multi-criteria evaluation techniques. Research Journal of ApplieSciences 5 (3): 242253. 
Food and Agriculture Organisation (FAO), 1976. A framework for land evaluation, Soils Bull., 32. Food and Agriculture Organization, Rome.

Food and Agriculture Organization (FAO). 1990. Beekeeping in Asia. Food and Agriculture Organization, Rome.

Forest Planning Agency. 2009. Map of forest area status. Forest Planning Agency, Ministry of Forestry

Giannini TC, Acosta AL, Garófalo CA, Saraiva AM, Alves-dos-Santos I, Imperatriz-Fonseca VL. 2012. Pollination services at risk: Bee habitats will decrease owing to climate change in Brazil. Ecological Modelling 244: 127-131.

Hannon LE, Sisk TD. 2009. Hedgerows in an agrinatural landscape: Potential habitat value for native bees. Biological Conservation 142: 2140-2154.

Hossain MS, Das NG. 2010. GIS-Based multi-criteria evaluation land suitability modelling for giant prawn Macrobrachium rosenbergii farming in Companigonj Upazila of Noakhali, Bangladesh. Computer and Electronics in Agriculture 70: 172-186.

Kementerian Kehutanan Republik Indonesia. 2016. Perlebahan di Indonesia. [internet] [cited 2015 June 23]. Available at: http://www.dephut.go.id/informasi/humas/leba h.htm.

Kusmana C. 2011. Forest resources and forestry in Indonesia. Forest Science and Technology 7(4): $155-160$.

Malczewski J. 2006. GIS-based multicriteria decision analysis: a survey of literature. International Journal of Geographic Informaton Science 20(7): 703-726.
Markwell TJ, Kelly D, Duncan KW. 1993. Competition between honey bees (Apis mellifera) and wasps (Vespula Spp.) in Honeydew Beech (Nothofagus Solandri Var. Solandri) forest. New Zealand Journal of Ecology 17(2): 85-93.

Park MS, Yeo-Chang Y. 2012. Traditional knowledge of Korean native beekeeping and sustainable forest management. Forest Policy and Economics 15: 37-45.

Pusat Penelitian Tanah. 1981. Penelitian tanah daerah Jabotabek (I, II dan III). Puslitan, Badan Litbang Departemen Pertanian.

Rachmawati N, Munibah K, Widiatmaka. 2014. Kesesuaian lahan untuk budidaya lebah madu dan arahan pengembangannya (studi kasus Kabupaten Cianjur). Globe 16 (1): 85-96.

Roman A. 2006. Effect of pollen load size on the weight of pollen harvested from honey bee colonies (Apis mellifera L). Journal of Apicultural Science 50(2): 47-57.

Saaty TL. 1988. The analytic hierarchy process. Suffolk: Typesetters Ltd., Becceles.

Store R., Jokimaki J. 2003. A GIS-based multi-scale approach to habitat suitability modeling. Ecological Modelling 169: 1-15.

Van Engelsdorp D. and Meixner MD. 2009. A historical review of managed honey bee populations in Europe and The United States and the factors that may affect them. Journal of Invertebrate Pathology 103: 80-95.

Widiarti A, Kuntadi. 2012. Budidaya lebah madu Apis mellifera L. oleh masyarakat pedesaan Kabupaten Pati, Jawa Tengah. Jurnal Penelitian Hutan dan Konservasi Alam 9(4): 351-361. 